\title{
Persepsi masyarakat desa munduk terhadap implementasi corporate social resposibility puri lumbung cottages
}

\author{
Ni Made Citra Pratiwi ${ }^{1}$ ), Anak Agung Putri Sri ${ }^{2)}$, Ni Putu Ratna Sari ${ }^{3)}$ \\ Program Studi Diploma IV Pariwisata, Fakultas Pariwisata, Universitas Udayana ${ }^{123)}$ \\ Jalan DR. R. Goris No. 7, Denpasar, Kode Pos : 80232, Telp/Fax : 0361-223798 \\ Email: madecitrapratiwi83@gmail.com ${ }^{1}$
}

\begin{abstract}
Abstrak
Suatu perusahaan tidak dapat dipisahkan dengan masyarakat sebagai lingkungan eksternalnya. Eksistensi perus ahaan bergantung dari hubung an timbal balik antara perus ahaan dengan mas yarakat. Perusahaandan mas yarakat adalah pasangan hidup yang saling memberi dan membutuhkan. Kontribusi dan harmonisasi keduanya akan menentukan keberhasilan pemb angunan bangsa. Adanya keselarasanantarakeuntunganyang diperoleh perus ahaan dengan pemberian kontribusi secara langsung kepada masyarakat dan lingkungannya merupakan mekanis me check \& balances antara pihak perusahaan dengan masyarakat. Dengan kata lain Corporate Social Res ponsibility (CSR) juga dipandang sebag ai tolok ukur untuk reputasi suatu perusahaan. Penelitian ini bertujuan untuk mengetahui implementasi serta persepsi masyarakat Desa Munduk terhadap Corporate Social Responsibilty. Jenis data yang digunakan dalampenelitian ini adalah data kualitatif dan kuantitatif. Teknik pengumpulan data adalah observasi, wawancara terstruktur, kuesioner, dan studi kepustakaan. Teknik penentuan informan adalah purposive sampling. Sampel yang digunakan adalah 98 responden dengan teknik penentuan sampel digunakan adalah accidental sampling. Analis is data yang digunakan adalah deskriptif kualitatif dan kuantitatif yang ditunjang dengan skala likert. ProgramCSRyang dilakukan oleh Puri Lumbung Cottages yaitu kepada mas yarakat sekitar Desa Munduk sudah dilaksanakan dengan baik. ProgramCSR berupa program kelas menari, kursus mas sage, cooking class, perpustakaandesa, konservasi air, pembagian bibit kopi, serta natural and conservation activity. Hasil penelitian menunjuk kan bah wa persepsimas yarakat terhadap implementasi CSR Puri Lumbung Cottages berdas arkankuesioneryang disebarkan ke 98 responden mas yarakat Des a Munduk mendapatkan skor penilaian akhirdenganrata-rataskor penilaian 3 dengan kategori sikap "baik".
\end{abstract}

Kata kunci: : Persepsi, implementasi, dan corporate social responsibilty

\begin{abstract}
Abs tract
A company can not be separated with the community as a eksternalnya environment. The existence of the company depends on the mutual relations between the company with the community. The company and the community is the life partner of mutual give and take. Contributions and the harmonization of the two will determine success of nation-building. The existence of harmony between the profitsthataccueto thecompany with the granting of a contribution directly to the society and its environment is a mechanis mcheckbalances between \& company with the community. In other words, Corporate Social Responsibility (CSR) is alsoseen as the benchmark for the reputation of a company. This research aims to know the implementation as wellas the public perception of the village of Munduk against Corporate Social Responsibilty. Types ofdatausedin this research is qualitative and quantitative data. Data collection techniques are observation, interview, questionnaire, and structured study of librarianship. The technique of determination of the informant was purposive sampling. The sample used is 98 respondents with the technique of deteminationofthesampleused is accidental sampling. The analy sis of the data used is descriptive qualitative and quantitative fit the scale likert. CSR programs undertaken by Puri Lumbung Cottages i.e to the community surrounding the villageof Munduk was implemented properly. CSR programin the formof programd ance classes, courses mas sage, cooking class, the village library, water conservation, Division of coffee seedlings, as well as natural and conservation activity. The results showed that the public perception towards CSR implementation Puri Lumbung Cottages based on a questionnaire that was distributed to the 98 villagers Mundukrespondents geta final as sessment score with the average score assessment 3 the attitude of the "good" category.
\end{abstract}

Keywords: Perception, implementation, and corporate social responsibility 


\section{PENDAHULUAN}

Suatu perusahaan tidak dapat dipisahkan dengan masyarakat sebagai lingkungan eksternalnya. Eksistensi perusahaan bergantung dari hubungan timbal balik antara perusahaan dengan masyarakat. Perusahaan dan masyarakat adalah pasangan hidup yang saling memberi dan membutuhkan. Adanya keselarasan antara keuntungan yang diperoleh perusahaan dengan pemberian kontribusi secara langsung kepada masyarakat dan lingkungannya merupakan mekanisme check \& balances antara pihak perusahaan dengan masyarakat. Dengan kata lain Corporate Social Responsibility (CSR) juga dipandang sebagai tolok ukur untuk reputasi suatu perusahaan. Bowem (1953) mendefinisikan CSR sebagai kewajiban pengusaha untuk merumuskan kebijakan, membuat keputusan atau mengikuti garis tindakan yang diinginkan dalam hal tujuan dan nilai-nilai masyarakat. Definisi tersebut kemudian diperbarui oleh Davis (1960) yang menyatakan bahwa keputusan dan tindakan bisnis diambil dengan alasan atau setidaknya sebagian melampaui kepentingan ekonomi atau teknis langsung perusahaan. CSR perusahaan akan mempengaruhi reputasi perusahaan itu.

CSR memiliki peran yang penting karena mempengaruhi semua aspek operasi perusahaan atau dengan kata lain semakin konsumen ingin membeli produk dari perusahaan yang mereka percaya maka pemasok semakin berminat untuk membentuk kemitraan bisnis dengan perusahaan-perusahaan mereka, karyawan ingin bekerja untuk perusahaan, dana investasi yang besar ingin mendukung perusahaan-perusahaan yang mereka anggap bertanggung jawab secara sosial, dan organisasi nirlaba dan LSM ingin bekerja sama dengan perusahaan untuk mencari solusi praktis untuk tujuan bersama. Kepuasan yang dirasakan masing-masing stakeholders memungkinkan perusahaan untuk memaksimalkan komitmen mereka untuk pemiliknya (pemegang saham utama) yang mendapat manfaat paling besar ketika semua kebutuhan kelompok-kelompok ini terpenuhi. Menurut Heimann (2008) menyebutkan beberapa alasan mengapa CSR perlu dilaksanakan:

1. Merupakan hal etis yang dilakukan

2. Meningkatkan citra perusahaan

3. Hal ini diperlukan dalam rangka untuk menghindari peraturan yang berlebihan

4. Jenis kegiatan dari tanggung jawab sosial dapat juga menguntungkan

5. Lingkungan sosial yang lebih baik akan bermanfaat bagi perusahaan

6. Dapat menarik minat para investor

7. Dapat meningkatkan motivasi karyaw an

8. Dapat membantu untuk memperbaiki masalah sosial yang disebabkan oleh bisnis.

CSR merupakan sebuah komitmen untuk meningkatkan kesejahteraan masyarakat melalui praktik bisnis. Meskipun demikian, hal ini bukan amal tetapi itu adalah strategi bisnis inti dari sebuah organisasi. Post et al. dalam Solihin (2009) menyatakan tanggung jawab sosial perusahaan merupakan salah satu dari beberapa tanggung jawab perusahaan kepada pemangku kepentingan. Pemangku kepentingan dalam hal ini adalah orang atau kelompok yang dapat mempengaruhi atau dapat dipengaruhi oleh berbagai keputusan, kebijakan maupun operasi perusahaan. Selanjutnya Jones 1995 dalam Solihin (2008) mengklasifikasikan pemangku kepentingan ke dalam 2 (dua) kategori, yaitu inside stakeholders yang terdiri dari pemegang saham (stakeholders), para manager (managers) dan karyaw an (employees) atau orang-orang yang memiliki kepentingan dan tuntutan terhadap sumber daya perusahaan serta berada didalam organisasi perusahaan. Sedangkan outside stakeholders terdiri dari orang-orang maupun pihak-pihak yang bukan pemilik perusahaan, bukan pemimpin perusahaan, dan bukan pula karyawan perusahaan, namun memiliki kepentingan terhadap perusahaan dan dipengaruhi oleh keputusan serta tindakan yang dilakukan oleh perusahaan.

Chakraborty (2010) menyimpulkan bahwa CSR adalah tentang perusahaan mengelolaproses bisnis untuk menghasilkan dampak positif secara keseluruhan pada masyarakat. Artinya, perusahaan harus mempertimbangkan kepentingan masyarakat dengan mengambil tanggung jawab atas dampak kegiatan mereka terhadap pelanggan, pemasok, pemegang saham karyawan, masyarakat dan pemangku kepentingan lainnya, serta lingkungan. Ini terlihat melampaui kewajiban hukum untuk mematuhi undang-undang sebagai organisasi sukarela dalam mengambil langkah lebih lanjut untuk 
meningkatkan kualitas hidup bagi karyawan dan keluarga mereka serta bagi masyarakat setempat dan masyarakat pada umumnya.

CSR merupakan wujud dari giving back dari perusahaan kepada komunitas atau masyarakat sekitar, yang dapat dilakukan untuk menghasilkan bisnis berdasarkan niat tulus guna memberi kontribusi yang paling positif pada masyarakat sekitar (stakeholders). Tujuan CSR bukan hanya pembangunan komunitas semata. Inti tujuan CSR yaitu bagaimana pembangunan komunitas bisa terus eksis berada dalam masyarakat sebagai upaya untuk keseimbangan lingkungan dan alam. Dalam menjalankan tanggung jaw ab sosialnya, perusahaan memfokuskan perhatiannya kepada tiga hal yaitu keuntungan, masyarakat, dan lingkungan. Dengan memperhatikan masyarakat, perusahaan dapat berkontribusi terhadap peningkatan kualitas hidup masyarakat. Perhatian terhadap masyarakat dapat dilakukan dengan cara perusahaan melakukan aktivitas-aktivitas serta pembuatan kebijakankebijakan yang dapat meningkatkan kesejahteraan, kualitas hidup dan kompetensi masyarakat di berbagai bidang. Dengan memperhatikan lingkungan, perusahaan dapat ikut berpartisipasi dalam usaha pelestarian lingkungan demi terpeliharanya kualitas hidup umat manusia dalam jangka panjang. Keterlibatan perusahaan dalam pemeliharaan dan pelestarian lingkungan berarti perusahaan berpartisipasi dalam usaha mecegah terjadinya bencana serta meminimalkan dampak bencana yang diakibatkan oleh kerusakan lingkungan. Dengan melakukan tanggung jawab sosial, perusahaan diharapkan tidak hanya mengejar laba jangka pendek, tetapi juga ikut berkontribusi terhadap peningkatan kualitas hidup masyarakat dan lingkungandalam jangka panjang. Intinya manfaat CSR bagi masyarakat yaitu dapat mengembangkan diri dan usahanya sehingga sasaran untuk mencapai kesejahteraan tercapai.

Adapun tujuan yang ingin dic apai dalam penelitian ini adalah untuk mengetahui program CSR pada Puri Lumbung Cottages dan mengetahui persepsi masyarakat terhadap penerapan CSR Puri Lumbung Cottages. Sedangkan manfaat akademis yang diperoleh melalui penelitian ini diharapkan mahasiswa dapat menganalisis berbagai masalah dan mampu memberikan pemecahan atau solusi dari permasalahan tersebut serta mahasiswa dapat mengaplikasikan ilmu serta konsep yang telah dipelajari selama perkuliahan. Selain itu, hasil dari penelitian ini juga diharapkan dapat memberikan wawasan serta pengetahuan bagi mahasiswa yang berkaitan dengan mata kuliah Public Relation. Manfaat praktisnya adalah bagi industri pariw is ata khususnya yang memiliki usaha di bidang sarana akomodasi sebagai masukan terkait program CSR yang diterapkan.

Penelitian terkait yang dijadikan sebagai acuan adalah penelitian yang diangkat oleh Dhisnin (2016) yang berjudul "Pengaruh Program CSR (Corporate Social Responsibility) Dalam Mempertahankan Citra Positif Di Lorin Solo Hotel". Tujuan penelitian ini adalah untuk mengetahui pengaruh program CSR (Corporate Social Responsibility) dalam mempertahankan citra positif. Penelitian ini dilakukan di Lorin Solo Hotel dengan analisis deskriptif kualitatif ditunjang dengan studi pustaka. Hasil dari penelitian ini adalah program CSR (Corporate Social Responsibility) berpengaruh terhadap citra positif di Lorin Solo Hal ini dapat dilihat berdasarkan kuesioner penelitian sebanyak 70.5\% responden menjawab Ya, tentang Pengaruh program CSR (Corporate Social Responsibility), sebanyak 90\% responden mengatakan Ya tentang Citra Positif. Kesimpulan dari penelitian ini adalah adanya pengaruh antara program CSR (Corporate Social Responsibility) dengan citra positif di Lorin Solo Hotel.

Penelitian kedua dilakukan oleh Pertiwi (2013) yang berjudul "Implementasi Corporate Social Responsibility Berlandaskan Budaya Tri Hita Karana”. Penelitian ini bertujuan untuk mengetahui dan memahami implementasi CSR berlandaskan Tri Hita Karana pada Discovery Kartika Plaza Hotel. Metode etnografi digunakan untuk mendapatkan informasi yang lebih mendalam dan utuh dari sudut pandang para informan. Hasil penelitian menemukan bahwa CSR terpadu berarti usaha perusahaan dalam menjalankan kegiatan bisnisnya secara lebih terintegrasi, baik antara tujuan perusahaan sebagai usaha bisnis, keharmonisan hubungan dengan masyarakat, alam, dan Tuhan. CSR Terpadu menghasilkan empat sinergi implementasi, yaitu implementasi di perusahaan, masyarakat, lingkungan, dan hal-hal yang berkaitan dengan Tuhan. 
Penelitian yang ketiga yakni oleh Sofyanty (2017) yang berjudul "Analisis Penerapan CSR dan Dampaknya Terhadap Kehidupan Sosial Ekonomi Masyarakat". Pelaksanaan CSR pada hotel tidak hanya terfokus pada laba tetapi juga harus memperhatikan lingkungan sosial dan juga perekonomian masyarakat sekitar. Namun dalam hal ini terdapat permasalahan di Hotel Ibis Surabaya City Center terkait penerapan CSR yang hanya diberikan kepada dua anak asuh dan juga keberadaan hotel yang tidak memberikan dampak pada segi perekonomian masyarakat sekitar. Data pada penulisan ini diambil melalui waw ancara, observasi dan dokumentasi. Hasil dari penelitian ini adalah Hotel Ibis Surabaya City Center telah menerapkan beberapa program CSR, namun ada satu CSR yang terhambat dikarenakan pendapatan Hotel Ibis Surabaya City Center yang tidak stabil. Hotel Ibis Surabaya City Center juga melaksanakan penanaman 1000 pohon di Desa Gerbo, Nongkojajar yang tidak tepat sasaran dikarenakan keberadaannya yang jauh dari lingkungan Hotel Ibis. Penerapan CSR Hotel Ibis Surabaya City Center masih belum sesuai dengan konsep triple bottom line dikarenakan pada aspek sosial pihak hotel tidak melibatkan masyarakat dalam aktivitas bisnisnya dan juga pihak hotel tidak memberdayakan masyarakat.

Tabel 1. Persamaan dan perbedaan dengan penelitian sebelumnya

\begin{tabular}{|c|c|c|c|}
\hline & & Perbedaan & Persamaan \\
\hline \multirow{5}{*}{$\begin{array}{c}\text { Pengaruh Program } \\
\text { CSR (Corporate } \\
\text { Social } \\
\text { Responsibility) } \\
\text { Dalam } \\
\text { Mempertahankan } \\
\text { Citra Positif Di } \\
\text { Lorin Solo Hotel }\end{array}$} & Tempat Penelitian & Lorin Solo Hotel & - \\
\hline & Objek Penelitian & Citra Perusahaan & $\begin{array}{c}\text { Corporate Social } \\
\text { Responsibility }(\text { CSR })\end{array}$ \\
\hline & $\begin{array}{c}\text { Teknik Penentuan } \\
\text { Sampel }\end{array}$ & - & - \\
\hline & Variabel & - & $\begin{array}{c}\text { Corporate Social } \\
\text { Responsibility }(\text { CSR }) \\
\end{array}$ \\
\hline & Teknik Analis is Data & - & $\begin{array}{l}\text { Deskriptif } \\
\text { Kualitatif }\end{array}$ \\
\hline \multirow{5}{*}{$\begin{array}{c}\text { Implementasi } \\
\text { Corporate Social } \\
\text { Responsibility } \\
\text { Berlandaskan } \\
\text { Budaya Tri Hita } \\
\text { Karana }\end{array}$} & Tempat Penelitian & $\begin{array}{c}\text { Dis covery Kartika Plaza } \\
\text { Hotel }\end{array}$ & - \\
\hline & Objek Penelitian & $\begin{array}{c}\text { Corporate Social } \\
\text { Responsibility }(\text { CSR }) \text { dan } \\
\text { THK }\end{array}$ & $\begin{array}{c}\text { Corporate Social } \\
\text { Responsibility }(\text { CSR })\end{array}$ \\
\hline & $\begin{array}{c}\text { Teknik Penentuan } \\
\text { Sampel } \\
\end{array}$ & - & - \\
\hline & Variabel & - & $\begin{array}{c}\text { Corporate Social } \\
\text { Responsibility }(\text { CSR }) \\
\end{array}$ \\
\hline & Teknik Analis is Data & $\begin{array}{c}\text { Metode } \\
\text { Etnografi } \\
\end{array}$ & - \\
\hline \multirow{4}{*}{$\begin{array}{l}\text { Analisis Penerapan } \\
\text { CSR dan } \\
\text { Dampaknya } \\
\text { Terhadap Kehidupan } \\
\text { Sosial Ekonomi } \\
\text { Masyarakat }\end{array}$} & Tempat Penelitian & $\begin{array}{c}\text { Hotel Ibis Surabaya City } \\
\text { Center }\end{array}$ & - \\
\hline & Objek Penelitian & $\begin{array}{c}\text { Dampak social ekonomi } \\
\text { Corporate Social } \\
\text { Responsibility }(C S R)\end{array}$ & $\begin{array}{c}\text { Corporate Social } \\
\text { Responsibility }(C S R)\end{array}$ \\
\hline & $\begin{array}{c}\text { Teknik Penentuan } \\
\text { Sampel }\end{array}$ & Probability Sampling & - \\
\hline & Teknik Analis is Data & - & Deskriptif Kualitatif \\
\hline
\end{tabular}

Sumber: Hasil Analis is Peneliti, 2018.

Persamaan penelitian ini dengan penelitian yang digunakan sebagai telaah adalah sama-sama membahas mengenai penerapan konsep CSR. Perbedaan dalam penelitian ini dan penelitian yang digunakan sebagai telaah dapat dilihat dari segi rumusan masalah atau pembahasan yang akan dibahas dan lokasi penelitian yang berbeda. 


\section{METODE PENELITIAN}

Lokasi penelitian ini adalah sebuah hotel bintang dua yang terletak di Banjar Taman, Desa Munduk, Kec. Banjar, Buleleng, Kabupaten Buleleng, Bali 81152, Indonesia. Munduk adalah sebuah desa pegunungan kecil, terletak antara 500 hingga 1200 meter di atas permukaan laut dan dengan suhu rata-rata 20 sampai $25^{\circ} \mathrm{C}$.

Dengan populasi 6.200 orang, Desa Munduk memiliki sejarah yang kaya. Legenda mengatakan bahwa Munduk dihuni oleh orang-orang dari pegunungan yang melarikan diri invasi semut. Beberapa warga kemudian pindah dari Klungkung dan bermukim kembali di Desa Munduk sekitar 200 sampai 300 tahun yang lalu. Sejarah berulang ketika Belanda memperluas kerajaan kolonial mereka dari Jawa ke Bali. Mereka juga mencapai Bali Selatan melalui Desa Munduk, dan kemudian menggunakannya sebagai jalan mundur dari ibukota administratif Singaraja. Hotel pertama untuk perwira Belanda dibuka di Munduk pada tahun 1908.

Dipilihnya Puri Lumbung Cottages sebagai lokasi penelitian berdasarkan adanya daya tarik penulis terkait hotel yang memiliki program CSR yang dijalankan secara rutin dan adanya tanggung jaw ab bagi perusahaan dengan komitmen untuk membangun suatu kehidupan yang sejahtera dengan masyarakat lokal dan lingkungan sekitar.

Guna memperjelas variabel-variabel yang digunakan dalam penelitian ini dan membatasi permasalahan yang dibahas dalam penelitian, maka perlu dijelaskan definisi operasional variabel dalam permasalahan yang akan dibahas. Secara operasional dapat dijelaskan sebagai berikut.

\section{Implementasi CSR}

A. People, merupakan lingkungan masyarakat dimana perusahaan berada. Mereka adalah para pihak yang mempengaruhi dan dipengaruhi perusahaan. Dengan demikian, community memiliki interelasi kuat dalam rangka menciptakan nilai bagi perusahaan. Hampir tidak mungkin, perusahaan mampu menjalankan operasi secara berkelanjutan tanpa didukung masyarakat sekitar. Disitulah letak terpenting dari kemajuan dan kemampuan perusahaan mendekatkan diri dengan masyarakat lew at strategi tanggung jawab sosial. Perusahaan harus memiliki kepedulian terhadap kesejahteraan manusia sekitar perusahaan maupun secara luas. Dalam penelitian ini merupakan program CSR yang diberikan kepada masyarakat sekitar maupun masyarakat secara luas oleh Puri Lumbung Cottages yaitu berupa program belajar menari, kursus massage, cooking class, dan perpustakaan baca.

B. Planet, merupakan lingkungan fisik memiliki signifikansi terhadap eksitensi perusahaan. Hubungan perusahaan dengan alam yang bersifat sebab akibat. Kerusakan lingkungan, eksploitasi tanpa batas keseimbangan, cepat atau lambat akan menghancurkan perusahaan dan masyarakat. Perusahaan haruslah peduli terhadap lingkungan hidup dan keberlanjutan keragaman hayati. Di Puri Lumbung Cottages program CSR berupa planet yaitu konservasi air, pemberian bibit kopi untuk masyarakat Desa Munduk, dan natural and conservation activity.

C. Profit, merupakan satu bentuk tanggung jawab yang harus dicapai perusahaan, bahkan tendensi ekonomi yang dijadikan pijakan filosofis operasional perusahaan, profit merupakan orientasi untuk mencari keuntungan ekonomi yang memungkinkannya untuk terus berkembang serta Memberikan manfaat sosial ekonomi kepada semua stakeholder.

\section{Persepsi Masyarakat}

Persepsi yang dimaksud dalam penelitian ini adalah pandangan atau penilaian masyarakat Desa Munduk terhadap implementasi CSR Puri Lumbung Cottages. Implementasi CSR sesuai dengan program yang sudah dilaksanakan Puri Lumbung Cottages yaitu program kelas menari, kursus massage, cooking class, perpustakaan baca, konservasi air, pembagian bibit kopi, natural and conservation activity. 
Data kualitatif yang dipergunakan dalam penelitian ini adalah data hasil waw ancara mengenai implementasi CSR di Puri Lumbung Cottages dan data kuantitatif yang dipergunakan dalam penelitian ini adalah data jumlah kamar dan fasilitas lainnya yang ada di Puri Lumbung Cottages, serta tarif yang diterapkan. Adapun sumber data dalam penelitian ini terbagi menjadi dua bagian, sebagai berikut data primer yakni hasil wawancara dengan Pendiri Puri Lumbung Cottages dan Karyaw an Puri Lumbung Cottages. Data sekunder yang digunakan dalam penelitian ini adalah arsiparsip Puri Lumbung Cottages.

Teknik Pengumpulan Data dilakukan dengan observasi yaitu melakukan pengamatan langsung ke lokasi penelitian untuk memperoleh gambaran yang jelas tentang program CSR pada Puri Lumbung Cottages, waw ancara terstruktur terhadap informan pangkal dan informan kunci. Dalam penelitian ini mewawancarai dua jenis informan yaitu informan pangkal dan informan kunci. Informan pangkal adalah Staff Puri Lumbung Cottages, Bapak Komang Agustadi, sedangkan informan kunci adalah Pendiri Puri Lumbung Cottages, Bapak I Nyoman Bagiarta. Pada penelitian ini responden mengisi kuesioner mengenai tanggapan masyarakat tentang dampak sosial ekonomi program CSR yang diterapkan pada Puri Lumbung Cottages dengan mengacu pada indikator yang telah tersedia dan melalui studi kepustakaan yaitu menggunakan literatur-literatur atau data yang bersumber dari buku serta penelitian sebelumnya tentunya yang berhubungan dengan penelitian ini.

Penentuan informan dalam penelitian ini menggunakan teknik Purposive Sampling. Informan yang diambil dalam penelitian ini adalah pendiri dan karyaw an Puri Lumbung Cottages. Populasi dalam penelitian ini adalah masyarakat yang ada di Desa Munduk. Jumlah populasi (masyarakat) di sekitar Puri Lumbung Cottages adalah 4706 orang, sehingga yang dijadikan sebagai sampel ditentukan dengan menggunakan rumus yang dikembangkan oleh Slovin (1990) yakni:

$$
\mathrm{n}=\frac{N}{1+N(e)^{2}}
$$

n : Ukuran Sampel

N : Ukuran Populasi (jumlah masyarakat di sekitar Puri Lumbung Cottages)

e : Persen kelonggaran ketidak telitian karena kesalahan pengambilan sampel yang ditolerir atau diinginkan, misalnya $1 \%, 5 \%$ dan $10 \%$.

Dalam penelitian ini presentase kelonggaran dalam kesalahan pengambilan sampel adalah $10 \%$.

$$
\begin{aligned}
\text { Sampel } & =\frac{4706}{1+4706(10 \%)^{2}} \\
& =\frac{4706}{1+4706(0,01)} \\
& =\frac{4706}{1+47,06} \\
& =\frac{4706}{48,06} \\
& =98 \text { responden }
\end{aligned}
$$

Jumlah sampel untuk mengetahui tanggapan masyarakat terhadap dampak sosial ekonomi dari program CSR Puri Lumbung Cottages ditetapkan sebanyak 98 responden. Teknik penyebaran 


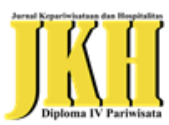

kuesioner menggunakan sistem quota. Teknik pengambilan sampel menggunakan accidental sampling. Teknik accidental sampling yakni pengambilan sampel yang diperoleh berdasarkan atas kebetulan bertemu di lokasi penelitian pada saat mencari data, dan dipandang orang yang kebetulan ditemui tersebut cocok sebagai sumber data.

Teknik analisis data yang digunakan adalah Analisis Deskriptif Kualitatif dengan mengumpulkan data yang diperoleh melalui pengamatan langsung (observasi) di lokasi penelitian, wawancara terstruktur kepada informan dan analisis skala likert yang menggunakan metode pengukuran (skala) pada jawaban-jawaban masyarakat dari koesioner yang diberikan kepada masyarakat untuk mengetahui dampak secara sosial ekonomi yang ditimbulkan dari program CSR Puri Lumbung Cottages. Setiap jaw aban yang diberikan oleh masyarakat memiliki bobot nilai yang berbeda dan jumlah alternative respon yang ada dalam skala likert ada 4 jenis (sangat setuju, setuju, tidak setuju, sangat tidak setuju).

Suatu pernyataan dalam item yang mengandung pernyataan positif akan diberikan skor sebagai berikut.

$\begin{array}{ll}\text { Sangat Baik } & =4 \\ \text { Baik } & =3 \\ \text { Tidak Baik } & =2 \\ \text { Sangat Tidak Baik } & =1\end{array}$

Skor akhir dalam skala likert diperoleh dengan menjumlahkan angka tiap- tiap jawaban. Sesuai dengan kategori yang diberikan yakni 1 (satu) untuk nilai terendah dan 4 (empat) untuk nilai tertinggi. Sedangkan untuk mencari rantang (interval) digunakan cara sebagai berikut ini:

$$
\begin{array}{cl}
\frac{\text { Skor tertinggi }- \text { Skor terendah }}{\text { Jumlah kategori }} & =\text { rentang nilai (interval) } \\
\frac{4-1}{4} & =0,75
\end{array}
$$

Tabel2. Skala Sikap Responden dari Program CSR Puri Lumbung Cottages

\begin{tabular}{|c|c|c|}
\hline Kriteria Penilaian & Skor & Kategori \\
\hline Sangat Baik & 4 & $3,26-4,00$ \\
\hline Baik & 3 & $2,51-3,25$ \\
\hline Tidak Baik & 2 & $1,76-2,50$ \\
\hline Sangat Tidak Baik & 1 & $1,00-1,75$ \\
\hline
\end{tabular}

Sumber: Sugiyono, 2014:168.

Berdasarkan rumus masalah, masing-masing kategori memiliki rentang nilai (interval) sebesar 0,75 .

\section{HASIL DAN PEMBAHASAN}

Puri Lumbung Cottages adalah sebuah eco-resort yang unik dan menghormati budaya tradisional Bali, lingkungan, penyembuhan, kesehatan, arsitektur, desain, seni, pertanian dan masakan. Puri Lumbung, yang berarti "gudang penyimpanan beras", sebuah eco-resort yang diatur di lokasi yang menakjubkan, di atas pegunungan dengan udara yang sejuk, segar, dan bersih, tepatnya di Munduk, Bali Utara, dengan pemandangan puncak gunung yang dramatis, sawah, lembah hijau 
subur, perkebunan cengkeh dan garis pantai Laut Jaw a di kejauhan. Pengalaman yang berbeda dari keindahan yang dimiliki Bali, jauh dari hawa panas biasanya. Dikelilingi oleh pemandangan alam terbaik, Puri Lumbung menaw arkan suasana damai, santai, dan asri. Selain sebuah akomodasi, Puri Lumbung juga menyediakan layanan meremajakan diri dengan penyembuhan dan kesehatan tradisional perawatan di tempat Arathi Spa. Puri Lumbung menyediakan beberapa paket, tetapi wisataw an juga bebas untuk membuat daftar keinginannya sendiri. Selain itu, Puri Lumbung juga memiliki kelas memasak, kelas membuat persembahan, kelas menenun, membuat kerajinan, membuat jamu, membuat alat musik bambu, juga kelas bahasa Bali atau bahasa Indonesia. Puri Lumbung juga menyediakan pemandu yang melayani keinginan untuk menjelajahi persaw ahan yang hijau, air terjun, perkebunan yang subur, juga berjalan sepanjang lereng gunung dan desa-desa tradisional di Munduk. Berlatih yoga dan meditasi juga bisa dilakukan di Puri Lumbung.

The "Lumbung" atau lumbung padi merupakan bagian dari warisan budaya Bali yang unik. Secara tradisional digunakan untuk menyimpan padi di bawah perlindungan dewi Dewi Sri, lumbung sekarang jarang digunakan karena teknik pertanian telah berubah. Lumbung-lumbung bekas rata-rata berusia 80 tahun, dengan sedikit penyesuaian diadaptasi menjadi akomodasi sederhana tapi menarik. Ritual khusus dilakukan untuk mengiring Dewi Sri kembali ke saw ah. Puri Lumbung diatur dalam udara pegunungan yang sejuk di mana kipas angin dan AC tidak diperlukan. Puri Lumbung dirancang dengan cara tradisional Bali meniru bentuk manusia suci dengan kuil di kepala, akomodasi tamu di jantung dan fasilitas lainnya di kaki.

Puri Lumbung adalah yang pertama dari jenisnya di Bali, Puri Lumbung lebih dari sebuah hotel, melainkan sebuah proyek eko-wisata yang didedikasikan untuk penemuan, konservasi dan peningkatan daerah yang belum terjamah di sekitar Munduk. Orang-orang dari Desa Munduk terlibat sebanyak mungkin dalam meraw at untuk para tamu. Tidak hanya menyediakan lapangan kerja, tetapi melibatkan mereka dalam kegiatan yang menjaga hutan hujan tropis dan melestarikan air, juga mendorong penduduk desa muda untuk menjaga warisan budaya mereka dengan tarian tradisional, musik dan kerajinan.

Adapun akomodasi dari Puri Lumbung antara lain:

1. 12 single and Double Cottages, 3 Family Cottages (6 rooms), 1 Deluxe Family Cottages (2 rooms) \& 2 Traditional Compound (2 rooms)

Dikelilingi oleh ladang hijau subur, kebun tropis dan kolam dengan pemandangan lembah saw ah yang hijau, pantai laut yang jauh dan dikelilingi gunung vulkanik. Family Cottages menyediakan ruang untuk keluarga atau kelompok sebanyak empat orang atau lebih dengan ruang tamu yang luas, kamar tidur, fasilitas kamar mandi, balkon yang terhubung, dan ruang tamu.

2. 6 Deluxe Alam Dewata Villas and 3 Deluxe Alam Dewata Cottages (5 rooms) Memiliki satu kamar tidur di lantai atas dengan balkon yang memiliki pemandangan indah dan twin bedroom di lantai bawah. Sebuah kamar tidur tambahan tersedia lantai bawah untuk menampung keluarga maximal enam orang. Dilengkapi juga dengan kamar mandi. Villa ini dirancang menggunakan arsitektur bergaya khas Bali dan dikelilingi oleh pemandangan dari ladang perkebunan cengkeh, kebun, dan kolam.

3. 3 Deluxe Taman Puri Villas and 6 Deluxe Taman Puri Cottages

Taman Puri Villas, setiap unit dapat menampung 3 orang. Maximal 5 orang dengan tempat tidur tambahan. Taman Puri Villa memiliki 3 unit, terletak di lokasi terbaik. Villa menghadapi ladang hijau, taman tropis, dan kolam. Unit 1 dilengkapi dengan kamar tidur dengan tempat tidur ganda di lantai atas, dengan 2 kamar tidur lebih di lantai dua. Unit 2 dan 3 terletak di lantai dasar. Masing-masing unit memiliki 2 kamar tidur dan kamar mandi pribadi mereka sendiri. Setiap unit dilengkapi dengan pendopo besar. Vila-vila ini dibangun dalam konsep tradisional unik. Setiap kamar memiliki bak mandi batu alam. Taman Puri Cottages, setiap unit Taman Puri Cottages terdiri dari 2 kamar tidur dan 2 kamar mandi, menampung hingga 4 orang. Dibangun dari kayu dan batu. Lantai atas memiliki kamar tidur utama dengan tempat tidur ganda. Sebuah kamar tidur 
kedua yang lebih kecil terletak di lantai dasar. Setiap kamar memiliki kamar mandi sendiri. Kedua kamar tidur terbuka ke beranda menghadap ke pemandangan yang indah. Taman Puri Cottages dikelilingi oleh taman tropis dan kolam dengan pemandangan lembah hijau dan pemandangan garis pantai Laut Jawa di kejauhan.

4. 6 rooms of Meme Surung homestay (600 meters from Puri Lumbung)

Kamar ini khusus bagi mereka yang ingin mengalami pengalaman tinggal dikamar bergaya kolonial khas Bali. Homestay ini bersih dan memiliki suasana khas desa yang ramah dan kamar mandi pribadi.

5. 8 rooms of Tamblang Nature Cabins (4km from Puri Lumbung)

Kamar ini khusus diatur dalam lingkungan hutan alam yang tenang, bagi mereka yang suka hidup di hutan dan ikut dalam pelestarian air untuk mendapatkan pengalaman yang benar-benar alami dan juga sekaligus melakukan meditasi.

Fasilitas kamar lengkap dan ramah lingkungan serta memberikan view yang menarik tergantung dari jenis dan lokasi kamar tersebut. Seluruh bangunan menggunakan konsep tradisional Bali yang dikemas baru, bersih, dan nyaman dan dilengkapi fasilitas seperti Warung Kopi Bali Restaurant, Taman Puri Courtyard, Laksmi Pond Garden, Artist Bar, Sunset Bar, Wantilan Victoria, Dhyana Hall, Mustika Hall \& Budha Dashara dan Arathi Spa \& Traditional Massage.

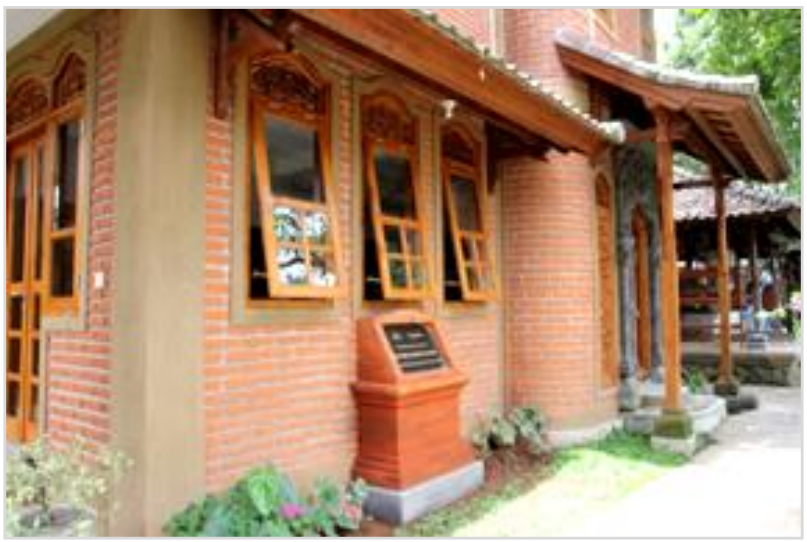

Gambar 1. Gedung yang didirikan oleh The Hellstren Family Switzerland

Sumber: Hasil Dokumentasi Penelitian, 2018.

Puri Lumbung terkenal dengan konsepnya yang ramah lingkungan. Menampilkan kekayaan alam, budaya, dan agama di dalam satu paket hotel. Puri Lumbung sendiri telah menerima banyak penghargaan, seperti pada tahun 2011 mendapatkan penghargaan Tri Hita Karana, Gold Award untuk kategori Melati Inns, Best of the best Melapa Melapi Awards 2015 (Balinese Food Festival 2015), dan juga Certific ate of Excellence 2015 from TripAdvisor. Selain penghargaan-penghargaan, Puri Lumbung juga sering kali mendapatkan bantuan dari organisasi Internasional, atas dedikasinya menjalankan hotel dan terus menjaga keberlangsungan alam sekitar mereka. Seperti bantuan pembuatan bangunan Subak Abian Meeting Hall yang didirikan oleh UNDP (United Nations Development Programme) atas dedikasi Puri Lumbung untuk memotivasi masyarakat Mundukuntuk melestarikan alam dan budaya mereka. Bantuan mendirikan bangunan dari The Hellstren Family Switzerland (Gambar 1). Bangunan ini didirikan sebagai tempat untuk komunitas belajar dan meneliti hal-hal terkait yang terjadi di sekitar Puri Lumbung untuk kebaikan dan perkembangan Puri Lumbung sendiri, serta lingkungan sekitarnya.

Untuk itu program CSR Puri Lumbung Cottages diupayakan pada program-program pengembangan masyarakat dan pengelolaan lingkungan yang merupakan asset penting dalam pariwisata. Sehingga dalam hal ini program CSR Puri Lumbung Cottages sejalan dengan konsep Triple Bottom Line (profit, people, planet) dengan memperhatikan keberlanjutan dari aspek masyarakat, lingkungan dan ekonomi. Bentuk-bentuk implementasi CSR yang diterapkan oleh Puri Lumbung Cottages adalah sebagai berikut. 


\section{Bentuk Implementasi People}

Bentuk implementasi yang dilaksanakan dalam lingkungan masyarakat dimana perusahaan berada dengan memberdayakan masyrakat sekitar. Dalam hal ini program yang dilakukan adalah :

A. Kelas Menari Oleh Puri Lumbung Cottages

Puri Lumbung juga menjalin hubungan yang baik antara hotel dan masyarakat setempat, dengan cara memberikan akses kepada masyarakat yang ingin belajar tari dan musik tradisional dapat melakukannya di hotel, menggunakan fasilitas yang disediakan oleh hotel. Kelas ini dilakukan setiap hari sabtu, di sore hari, yang diikuti oleh kebanyakan anak-anak sekitar Puri Lumbung. Juga kepada masyarakat yang ingin mengikuti kelas masak makanan tradisional Bali, hotel juga ikut memberikan akses. Hal ini dilakukan agar mendorong masyarakat untuk ikut berperan aktif dalam usaha melindungi kekayaan budaya lokal yang ada. Hotel juga menyediakan layanan kursus bahasa Inggris gratis kepada anak-anak setempat untuk sekali lagi membantu meningkatkan kualitas anak-anak desa setempat.

B. Kursus Massage

Kursus massage merupakan salah satu program CSR Puri Lumbung Cottages. Program ini ditargetkan untuk masyarakat Desa Munduk, selain diberikan pelatihan teknik massage yang baik dan benar, peserta juga diajarkan cara memberikan service yang baik dan benar. Hal ini dilakukan karena setelah selesai program pelatihan massage, peserta akan diberikan kesempatan untuk memberikan service massage kepada wisatawan yang menginap di Puri Lumbung Cottages.

C. Cooking Class

Puri Lumbung Cottages memiliki kegiatan cooking class yang diberikan kepada masyarakat sekitar serta pelanggan/tamu hotel tersebut. Kegiatan ini merupakan bentuk apresiasi bagi pengunjung yang menginap. Cooking class ini akan dibantu oleh para karyawan pada departemen food and beverage. Cooking class ini dilakukan setiap tahun sekali. Kegiatan ini dilakukan dengan tujuan agar pengunjung tidak merasa jenuh dan ingin kembali lagi menginap di Puri Lumbung Cottages serta dapat memberikan edukasi bagi masyarakat sekitar cara memasak sesuai dengan SOP di dunia hospitality.

D. Purpustakaan Baca

Perpustakaan baca ini dibuat agar meningkatkan minat baca masyarakat khususnya anak-anakdi Desa Munduk. Perpustakaan baca setiap hari dibuka dan terbuka untuk siapa saja yang ingin membaca. Hari Sabtu merupakan hari dimana perpustakaan baca dipenuhi pengunjung, hal ini dikarenakan anak-anak yang ikut program kelas menari sebelum latihan sebagian peserta ke perpustakaan terlebih dahulu.

\section{Bentuk Implementasi Planet}

Wujud kepedulian Puri Lumbung Cottages terhadap lingkungan sekitar dilakukan dengan melaksanakan kegiatan sebagai berikut :

A. Puri Lumbung Sebagai Pemasok Air di Desa Munduk

Berbicara mengenai air, Puri Lumbung sangatlah sensitif dengan hal tersebut. Karena menurut pemahaman hotel, air adalah sumber kehidupan dan mengandung unsur religious. Sehingga harus diperhatikan lebih baik lagi. Dalam hal ini Puri Lumbung memiliki properti konservasi air di Desa Munduk yang diperuntungkan untuk kesejahteraan bersama. Properti ini digunakan untuk memasok air ke seluruh desa, diberikan secara gratis, sebagai bentuk CSR dari hotel. Selain hal tersebut salah satu pendiri Puri Lumbung, Bapak Nyoman Bagiarta telah mengajukan konservasi Danau Tamblingan sejak pertama berdirinya hotel, hingga akhirnya pada 2016 disetujui dan siap untuk dilaksanakan. Hal ini dilandaskan akan pemahaman bahwa air adalah elemen penting dalam keberlangsungan hidup manusia. Selain hal ini Puri Lumbung juga rutin mengadakan acara-acara bersih-bersih bersama masyarakat seperti Clean Up Plastic Waste Munduk. Kegiatan ini dilakukan untuk membersihkan wilayah sekitar dari sampah-sampah plastic yang ada. Menanam pohon dan melestarikan alam bukan hanya dilakukan oleh karyawan, 
tetapi hal ini juga dimasukkan dalam salah satu aktivitas yang dapat dilakukan bersama oleh tamu hotel.

\section{B. Pembagian Bibit Kopi}

Pembagian bibit kopi dilakukan setiap musim tanam. Bibit kopi diberikan kepada seluruh petani Desa Munduk. Tujuan program ini agar petani kopi Desa Munduk melestarikan tanaman kopi arabika khas munduk. Puri Lumbung Cottages sangat memperhatikan budaya tanam di Desa Munduk karena hal ini penting agar tidak tergilas jaman, dan meninggalkan budaya tanam. Munduk dan sekitarnya memang penghasil kopi sejak zaman kolonial. Ingatan warga atas kopi begitu kuat hal ini disampaikan oleh Bapak Nyoman Niryasa selaku Kepala Desa yang menyatakan bahwa; Di Desa Munduk, para petani selain bertumpu pada dua komoditas cengkeh dan kopi, mereka juga bertani bunga pecah seribu. Serapan pasarnya tinggi mengingat bunga ini kerap menjadi bahan utama dalam upacara. Selain itu, dengan kondisi alamnya yang memikat, Munduk juga menjadi jujukan wisataw an. Dengan makin banyaknya kedai kopi yang tumbuh di berbagai kota, serapan kopi di Desa Munduk dan sekitarnya pun tinggi. Kopi sebanyak itu selain diambil dari wilayah Gobleg, juga dari Wanagiri, dan tentu saja Desa Munduk. Melihat peluang ini pihak management Puri Lumung Cottages menerapkan program CSR pembagian bibit kopi dengan tujuan membantu perekonomian masyarakat Desa Munduk.

C. Natural and Activity

Program ini merupakan suatu gerakan atau movement mengajak masyarakat serta wisataw an untuk melestarikan lingkungan sekitar khususnya di Desa Munduk. Program ini merupakan suatu paket trekking untuk w isataw an, didalam paket trekking ini wisataw an diberikan edukasi bercocok tanam dari proses pembibitan sampai panen. Edukasi diberikan atau dipandu oleh petani lokal yang sudah diberikan pelatihan cara memberikan service dalam bidang hospitality.

Pihak Manajemen menerapkan program CSR berdasarkan beberapa aspek yang terkandung di dalam pengembangan pariwisata yang berkelanjutan, yaitu :

1. Keberlanjutan dalam bidang ekonomi

A. memberikan keuntungan bukan hanya untuk saat ini tetapi juga untuk jangka panjang.

B. Membentuk kemitraan pada semua rantai pemasok mulai dari bisnis skala mikro hingga lembaga multinasional.

C. Menggunakan pedoman yang diakui ditingkat internasional dan pedoman pelatihan yang telah disertifikasi.

D. Mempromosikan kode etik dan perilaku yang berwawasan lingkungan pada para pengunjung.

E. Diversifikasi produk dengan mengembangkan kegiatan wisata yang bervariasi.

F. Mengkontribusikan sebagian keuntungan untuk membantu pelatihan, pengembangan produk dan pemasaran yang berwaw asan lingkungan.

G. Menyediakan intensif ekonomi untuk bisnis skala kecil dalam menerapkan prinsip berkelanjutan.

1. Keberlanjutan secara ekologi

A. pengembangan yang sesuai dengan pemeliharaan inti dari proses ekologi, keanekaragaman hayati dan sumber daya biologi.

B. Panduan implementasi harus dikembangkan pada semua tingkatan.

C. Panduan tentang prosedur standar oprasi, kajian dampak, dan monitoring harus dikembangkan.

D. Mempormulasikan kebijakan dan strategi pengembangan yang sesuai dengan tujuan pembangunan berkelanjutan di tingkat lokal, nasional, dan regional.

E. Memastikan bahwa desain, perencanaan dan oprasi dari fasilitas sesuai dengan prinsip berkelanjutan.

F. Memastikan pariwisata di kawasan konservasi harus sejalan dengan perencanaan pengelolaan konservasi.

G. Memonitor dan melakukan riset untuk dampak dari kegiatan pariwisata. 
H. Mempromosikan pariwisata bertanggung jawab.

I. Meningkatkan kontrol masyarakat terhadap perubahan nilai-nilai budaya dan memperkuat identitas masyarakat.

$\mathrm{J}$.

\section{Bentuk Implementasi Profit}

Dalam upaya mendapatkan keuntungan ekonomi yang positif, Puri Lumbung haruslah memastikan kegiatan ekonomi jangka panjang yang layak, memberikan manfaat sosial ekonomi kepada semua stakeholder dengan adil, seperti pekerjaan tetap, kesempatan mendapatkan penghasilan (membuka usaha) dan pelayanan sosial kepada masyarakat lokal, serta membantu mengurangi kemiskinan.

Kepemilikan lokal Pemilik, pemegang saham, pendiri, serta pekerja dari Puri Lumbung sendiri adalah masyarakat lokal Bali terkhususnya masyarakat Desa Munduk yang memiliki keinginan untuk bergabung di dalam pariwisata Bali, tetapi tidak melupakan pentingnya alam dan budaya lokal yang ada. Sejak aw al berdiri hingga 2016 ini, mereka masih tetap menanamkan prinsip yang sama.

Partisipasi masyarakat setempat terus mengawasi dan berperan langsung dalam pengembangan Puri Lumbung. Karena para staff dan bahkan pemilik Puri Lumbung ini adalah masyarakat lokal sendiri. Keterlibatan masyarakat dapar terlihat dalam aksi-aksi social dalam pensejahteraan masyarakat yang dilakukan oleh Puri Lumbung. Minat dan ketertarikan masyarakat terlihat sangat besar, seperti ketika Puri Lumbung berulangtahun, masyarakat lokal juga turut memeriahkan acara yang diadakan oleh Puri Lumbung. Dan ketika muncul desas-desus mengenai issue-issue negative hotel, masyarakat dan hotel akan melakukan diskusi terbuka untuk meluruskan isu-isu yang terdengar.

Menjaga budaya dan lingkungan sekitar bukan hanya visi dari hotel ini, berarti bukan hanya hotel yang memiliki kewajiban tersebut. Masyarakat juga harus turut melindungi alam dan budaya lokal yang ada. Seperti keikutsertaan masyarakat dalam mengimplementasi prinsip-prinsip berkelanjutan dan contohnya adalah ketika masyarakat turut serta melakukan bersih-bersih desa bersama pihak Puri Lumbung. Tentu saja kepuasaan pelanggan adalah yang paling utama dari sebuah bisnis komersil, begitu juga dengan Puri Lumbung. Uniknya, Puri Lumbung dibangun dan didirikan dengan pemikiran dan konsep bahwa, keuntungan yang sebenarnya adalah ketika seluruh elemen sekitar dapat merasakannya. Maka dari itu, hotel ini didirikan menggunakan konsep berkelanjutan dan didukung oleh prinsip lokal Tri Hita Karana. Sehingga, segala sesuatu yang dilakukan tidak pernah mengeyampingkan kepentingan stakeholder lainnya. Seperti, perekrutan karyawan yang seratus persen adalah masyarakat lokal dan masyarakat sekitar desa, juga dengan kepemilikan dimiliki oleh masyarakat sendiri. Dan juga terdapat beberapa volunteer orang asing yang bekerja di bagian pengobatan tradisional dan spa.

Puri Lumbung juga ikut menjamin kesejahteraan masyarakat Munduk dengan rutin melaksanakan acara-acara sosial, seperti yang dilakukan Puri Lumbung pada 13 Oktober 2016 dalam rangka memperingati hari jadi ke-24 tahun Puri Lumbung mengadakan bakti sosial di SDN 02 Munduk terkait cara mencuci tangan yang benar dan pemanfaatan air. Hal lainnya adalah Puri Lumbung berperan sebagai pemasok air masyarakat di Desa Munduk. Properti konservasi air yang dimiliki Puri Lumbung, mensubsidi seluruh kebutuhan air masyarakat di desa setempat. Dan dalam memenuhi kebutuhan hotel, Puri Lumbung menggunakan bahan dasar yang disediakan oleh masyarakat sekitar, tidak mengimpor dari luar, tetapi memanfaatkan hasil daerah setempat. Hal ini dilakukan untuk memberikan peluang kepada masyarakat lokal untuk mengembangkan bisnis mereka dan menuntaskan masalah kemiskinan yang ada.

Perekrutan yang dilakukan oleh Puri Lumbung sampai 2016 ini masih bertitik berat pada masyarakat lokal itu sendiri. Masyarakat yang direkrut sebagai karyawan diberikan pelatihan khusus terlebih dahulu. Mereka yang ingin melakukan training dipersilahkan dan juga diberikan gaji, guna mensejahterahkan kehidupan masyarakat sekitar. Selain itu, setiap karyaw an dipastikan sebelum bekerja sebagai pegawai tetap dikirim kursus di IALF (Indonesian Australian Language Fondation) untuk meningkatkan kemampuannya, juga beberapa karyaw an dikirim untuk melakukan training di 
tempat lain, beberapa dikirim keluar negeri. Juga beberapa anak daerah yang berpotensi dan tertarik diberikan beasiswa ke sekolah-sekolah pariwisata seperti STP (Sekolah Tinggi Pariwisata) dan sekolah swasta pariwisata lainnya. Hal ini dilakukan hotel karena menurut mereka daripada menggunakan karyawan dari luar yang terlatih, lebih baik melatih orang dalam itu sendiri dan meningkatkan kualitasnya. Selain memberi keuntungan hotel juga memberikan dampak yang baik kepada lingkungan sekitar.

Persepsi Masyarakat terhadap CSR pada Puri Lumbung Cottages terkait dengan karakteristik responden dan Persepsi Masyarakat Tehadap CSR pada Puri Lumbung Cottages.

\section{Karakteristik Responden}

Penelitian ini erat kaitanya dengan masyarakat, dalam penelitian ini terjadi interaksi yang melibatkan masyarakat sebagai informan. Masyarakat diberikan kuesioner yang berisi pertanyaan terkait implementasi CSR Puri Lumbung Cottages, masyarakat menjawab setiap pertanyaan sesuai dengan pendapatnya dan sesuai dengan fakta. Berikut merupakan karakteristik masyarakat yang ada di Desa Munduk dalam hal ini sebagai responden yang telah mengisi kuesioner dalam penelitian ini.

Tabel3. Karakteristik Mas yarakat Berdasarkan Jenis Kelamin

\begin{tabular}{|c|l|c|c|}
\hline No & Jenis Kelamin & Jumlah (Orang) & Persentase (\%) \\
\hline 1 & Laki-laki & 64 & 65,30 \\
\hline 2 & Perempuan & 34 & 34,70 \\
\hline & Total & 98 & 100,00 \\
\hline
\end{tabular}

Sumber: Diolah dari data penelitian, 2018.

Data pada Tabel 3 dapat diketahui bahwa mayoritas yang memberikan tanggapan mengenai implementasi CSR Puri Lumbung Cottages yaitu masyarakat berjenis kelamin laki-laki sebanyak 64 orang masyarakat dengan persentase $65,3 \%$, sedangkan masyarakat yang berjenis kelamin perempuan sebanyak 35 orang dengan persentase 34,7\% masyarakat. Hal ini di Desa Munduk untuk perempuan yang masih single lebih banyak bekerja di luar daerah dan ada pula yang bersekolah diluar daerah, sedangkan untuk ibu-ibunya lebih banyak bekerja sebagai petani dan bekerja di dalam rumah serta karyawan villa sehingga jarang ditemukan diluar rumah.

Tabel4. Karakteris tik Mas yarakat Berdasarkan TingkatUmur

\begin{tabular}{|c|c|c|c|}
\hline No & Umur (Tahun) & Jumlah (Orang) & Persentase (\%) \\
\hline 1 & $\leq 19$ & 5 & 5,10 \\
\hline 2 & $20-29$ & 56 & 57,14 \\
\hline 3 & $30-39$ & 25 & 25,51 \\
\hline 4 & $40-49$ & 9 & 9,18 \\
\hline 5 & $\geq 50$ & 3 & 3,07 \\
\hline & Total & 98 & 100.00 \\
\hline
\end{tabular}

Sumber: Diolah dari data penelitian, 2018.

Berdasarkan data pada Tabel 4 dapat diketahui bahwa mayoritas yang memberikan tanggapan terhadap implementassi CSR Puri Lumbung Cottages adalah masyarakat dengan rentang usia 20-29 tahun sebanyak 56 orang atau dengan persentase 57,14\% masyarakat, dan yang terendah yaitu masyarakat yang berusia $\geq 50$ sebanyak 3 orang atau 3,07\% masyarakat.

Tabel 5. Karakteristik Mas yarakat Berdasarkan Status

\begin{tabular}{|c|l|c|c|}
\hline No & Status & Jumlah (Orang) & Persentase (\%) \\
\hline 1 & Belum Kawin & 47 & 48,00 \\
\hline 2 & Kawin & 51 & 52,00 \\
\hline & Total & 98 & 100,00 \\
\hline
\end{tabular}

Sumber: Diolah dari data penelitian, 2018 
Berdasarkan data pada Tabel 5 dapat diketahui bahwa jumlah masyarakat yang memberikan tanggapan mengenai implementasi CSR Puri Lumbung Cottages baik yang berstatus belum kawin atau yang berstatus kawin memiliki jumlah yang hampir sama dimana jumlah masyarakat yang berstatus belum kawin sebanyak 47 orang atau $48,00 \%$ dan masyarakat yang kaw in sebanyak 51 orang atau $52,00 \%$. Jumlah masyarakat yang berstatus single dan keluarga yang telah mengisi kuesioner memiliki jumlah sang beda tipis.

Tabel6. Karakteristik Mas yarakat Berdasarkan TingkatPendidikan

\begin{tabular}{|c|l|c|c|}
\hline No & Tingkat Pendidikan & Jumlah (Orang) & Persentase (\%) \\
\hline 1 & SD & 8 & 8,16 \\
\hline 2 & SMP & 18 & 18,47 \\
\hline 3 & SMA/SMK & 49 & 50,00 \\
\hline 4 & S1-D4 & 10 & 10,20 \\
\hline 5 & S1/Sarjana & 13 & 13,10 \\
\hline & Total & 98 & 100,00 \\
\hline
\end{tabular}

Sumber: Diolah dari data penelitian, 2018.

Berdasarkan data pada Tabel 6 menunjukan bahwa tingkat pendidikan masyarakat Desa Munduk sangat beragam. Mayoritas masyarakat yang memberikan tanggapan terhadap CSR Puri Lumbung Cottages yaitu masyarakat yang berpendidikan SMA/SMK sebanyak 49 orang atau $50,00 \%$ dan yang terendah dari masyarakat yang berpendidikan sampai Sekolah Dasar (SD) sebanyak 8 orang atau $8,16 \%$.

Tabe17. Karakteristik Mas yarakat Berdasarkan Jenis Pekerjaan

\begin{tabular}{|c|l|c|c|}
\hline No & Pekerjaan & Jumlah (Orang) & Persentase (\%) \\
\hline 1 & PegawaiNegeri Sipil & 1 & 1 \\
\hline 2 & Wiras wasta & 30 & 30 \\
\hline 3 & Petani & 27 & 27 \\
\hline 4 & Pegawai Swasta & 42 & 42 \\
\hline & Total & 100 & 100,00 \\
\hline
\end{tabular}

Sumber: Diolah dari data penelitian, 2018.

Berdasarkan data pada Tabel 7 masyarakat yang paling banyak memberikan tanggapan terhadap CSR Puri Lumbung Cottages yakni masyarakat yang bekerja sebagai pegawai swasta sebanyak 42 orang dengan persentase $42 \%$ sedangkan yang terendah yaitu 1 orang pegaw ai swasta memberikan tanggapan dengan persentase $1 \%$.

\section{Persepsi Masyarakat Tehadap CSR pada Puri Lumbung Cottages}

Persepsi masyarakat dilakukan dengan memberikan kuesioner kepada beberapa masyarakat sebagai perwakilan di masing-masing banjar yang ada di Desa Munduk. Masing-masing responden diberikan kuesioner yang sama pertanyaanya berkaitan dengan persepsi masyarakat terhadap dampak sosial ekonomi CSR bagi masyarakat sekitar Puri Lumbung Cottages. Masyarakat yang diberikan kuesioner adalah masyarakat yang ditemui pada saat penyebaran kuesioner ke tiap-tiap banjar dan dirasa sesuai, sehingga karakteristik responden beragam. Berikut ini merupakan tanggapan masyarakat terhadap dampak sosial ekonomi CSR bagi masyarakat sekitar Puri Lumbung Cottages dapat dilihat pada Tabel 8 . 
Tabel 8. Persepsi MasyarakatTerhadap Kelas Menari

\begin{tabular}{|c|l|c|c|c|}
\hline No & Tanggapan & Skor & Responden & Jumlah \\
\hline 1 & Sangat Baik & 4 & 19 & 76 \\
\hline 2 & Baik & 3 & 75 & 225 \\
\hline 3 & Tidak Baik & 2 & 4 & 8 \\
\hline 4 & Sangat Tidak Baik & 1 & 0 & 0 \\
\hline \multicolumn{2}{|c|}{ Total } & 98 & 309 \\
\hline \multicolumn{2}{|c|}{ Rata-rata } & 3,15 \\
\hline
\end{tabular}

Sumber: Diolah dari data penelitian, 2018.

Berdasarkan hasil Skala Likert diperoleh total skor 309 dengan rata-rata 3,15. Angka tersebut di peroleh dari total perkalian antara skor tanggapan dengan jumlah responden yang memilih, kemudian dibagi dengan total responden. Kategori dengan skor 3,15 termasuk dalam kategori baik.

Tabe19. Persepsi Masyarakatterhadap Kursus Massage

\begin{tabular}{|c|l|c|c|c|}
\hline No & Tanggapan & Skor & Responden & Jumlah \\
\hline 1 & Sangat Baik & 4 & 18 & 72 \\
\hline 2 & Baik & 3 & 75 & 225 \\
\hline 3 & Tidak Baik & 2 & 5 & 10 \\
\hline 4 & Sangat Tidak Baik & 1 & 0 & 0 \\
\hline \multicolumn{2}{|c|}{ Total } & 98 & 307 \\
\hline \multicolumn{2}{|c|}{ Rata-rata } & 3,13 \\
\hline
\end{tabular}

Sumber: Diolah dari data penelitian, 2018.

Berdasarkan data pada Tabel 9 di atas dapat dilihat tanggapan masyarakat terhadap CSR bagi masyarakat sekitar Puri Lumbung Cottages yaitu tertinggi 75 orang masyarakat menyatakan baik dan terendah 5 orang yang menyatakan tidak baik. Hasil perhitungan skala likert diperoleh skor 307 dengan rata-rata 3,13. Kategori dengan skor 3,13 termasuk dalam kategori baik.

Tabel 10. Pers epsi Masyarakat Terhadap Cooking Class

\begin{tabular}{|c|l|c|c|c|}
\hline No & Tanggapan & Skor & Responden & Jumlah \\
\hline 1 & Sangat Baik & 4 & 21 & 84 \\
\hline 2 & Baik & 3 & 52 & 156 \\
\hline 3 & Tidak Baik & 2 & 25 & 50 \\
\hline 4 & Sangat Tidak Baik & 1 & 0 & 0 \\
\hline \multicolumn{2}{|c|}{ Total } & 98 & 290 \\
\hline \multicolumn{2}{|c|}{ Rata-rata } & 2,95 \\
\hline
\end{tabular}

Sumber: Diolah dari data penelitian, 2018.

Berdasarkan data pada Tabel 10 di atas dapat dilihat tanggapan masyarakat terhadap Cooking Class yang dilaksanakan Puri Lumbung Cottages yaitu tertinggi 52 orang masyarakat menyatakan baik, 25 orang masyarakat menyatakan tidak baik dan 21 orang masyarakat menyatakan sangat baik. 
Hasil perhitungan skala likert diperoleh skor 290 dengan rata-rata 2,95. Kategori dengan skor 2,95 termasuk dalam kategori baik.

Tabel 11. Persepsi Masyarakat terhadap Perpustakaan Desa

\begin{tabular}{|c|l|c|c|c|}
\hline No & Tanggapan & Skor & Responden & Jumlah \\
\hline 1 & Sangat Baik & 4 & 18 & 72 \\
\hline 2 & Baik & 3 & 56 & 168 \\
\hline 3 & Tidak Baik & 2 & 24 & 48 \\
\hline 4 & Sangat Tidak Baik & 1 & 0 & 0 \\
\hline \multicolumn{2}{|c|}{ Total } & 98 & 288 \\
\hline \multicolumn{2}{|c|}{ Rata-rata } & \multicolumn{2}{c|}{2,93} \\
\hline
\end{tabular}

Sumber: Diolah dari data penelitian, 2018.

Berdasarkan data pada Tabel 11 dapat dilihat tanggapan masyarakat terhadap perpustakaan desa di Puri Lumbung Cottages yaitu tertinggi 56 orang masyarakat menyatakan baik, 24 orang masyarakat menyatakan tidak baik dan terendah 18 orang masyarakat menyatakan sangat baik. Hasil perhitungan skala likert diperoleh skor 288 dengan rata-rata 2,93. Kategori dengan skor 2,93 termasuk dalam kategori baik.

Tabel 12. Persepsi Masyarakat terhadap Konservasi Air

\begin{tabular}{|c|l|c|c|c|}
\hline No & \multicolumn{1}{|c|}{ Tanggapan } & Skor & Responden & Jumlah \\
\hline 1 & Sangat Baik & 4 & 5 & 20 \\
\hline 2 & Baik & 3 & 70 & 210 \\
\hline 3 & Tidak Baik & 2 & 23 & 46 \\
\hline 4 & Sangan Tidak Baik & 1 & 0 & 0 \\
\hline \multicolumn{2}{|c|}{ Total } & 98 & 276 \\
\hline \multicolumn{2}{|c|}{ Rata-rata } & \multicolumn{2}{c|}{} \\
\hline
\end{tabular}

Sumber: Diolah dari data penelitian, 2018.

Berdasarkan data pada Tabel 12 dapat dilihat persepsi masyarakat terhadap konservasi air di Desa Munduk yang tertinggi sebanyak 70 orang masyarakat menyatakan baik, 23 orang masyarakat yang menyatakan tidak baik dan terendah 5 orang yang menyatakan sangat baik. Hasil perhitungan skala likert diperoleh skor 276 dengan rata-rata 2,81. Kategori dengan skor 2,81 termasuk dalam kategori baik.

Tabel 13. Persepsi Masyarakat terhadap Pembagian Bibit Kopi

\begin{tabular}{|c|l|c|c|c|}
\hline No & Tanggapan & Skor & Responden & Jumlah \\
\hline 1 & Sangat Baik & 4 & 18 & 72 \\
\hline 2 & Baik & 3 & 75 & 225 \\
\hline 3 & Tidak Baik & 2 & 5 & 10 \\
\hline 4 & Sangan Tidak Baik & 1 & 0 & 0 \\
\hline \multicolumn{2}{|c|}{ Total } & 98 & 307 \\
\hline \multicolumn{2}{|c|}{ Rata-rata } & \multicolumn{2}{c|}{} \\
\hline
\end{tabular}

Sumber: Diolah daridata penelitian, 2018 
Berdasarkan data pada Tabel 13 dapat dilihat tanggapan masyarakat terhadap CSR bagi masyarakat sekitar Puri Lumbung Cottages yaitu tertinggi 75 orang masyarakat menyatakan baik dan terendah 5 orang yang menyatakan tidak baik. Hasil perhitungan skala likert diperoleh skor 307 dengan rata-rata 3,13. Kategori dengan skor 3,13 termasuk dalam kategori baik.

Tabel 14. Persepsi Masyarakat Terhadap Natural and Conservation Activity

\begin{tabular}{|c|l|c|c|c|}
\hline No & \multicolumn{1}{|c|}{ Tanggapan } & Skor & Responden & Jumlah \\
\hline 1 & Sangat Baik & 4 & 21 & 84 \\
\hline 2 & Baik & 3 & 52 & 156 \\
\hline 3 & Tidak Baik & 2 & 25 & 50 \\
\hline 4 & Sangat Tidak Baik & 1 & 0 & 0 \\
\hline \multicolumn{2}{|c|}{ Total } & 98 & 290 \\
\hline \multicolumn{2}{|c|}{ Rata-rata } & \multicolumn{2}{c|}{2,95} \\
\hline
\end{tabular}

Sumber: Diolah dari data penelitian, 2018

Berdasarkan data pada Tabel 14 dapat dilihat tanggapan masyarakat terhadap natural and conservation activity yang dilaksanakan Puri Lumbung Cottages yaitu tertinggi 52 orang masyarakat menyatakan baik, 25 orang masyarakat menyatakan tidak baik dan 21 orang masyarakat menyatakan sangat baik. Hasil perhitungan skala likert diperoleh skor 290 dengan rata-rata 2,95. Kategori dengan skor 2,95 termasuk dalam kategori baik.

Berikut ini adalah hasil dari rekapitulasi dari persepsi masyarakat terhadap dampak sosial ekonomi CSR bagi masyarakat sekitar Puri Lumbung Cottages akan diuraikan pada Tabel 4.13.

Tabel 15. Rekapitulasi Persepsi Masyarakat Terhadap Implementasi CSR pada Puri Lumbung Cottages

\begin{tabular}{|c|c|c|c|c|}
\hline No. & Indikator & $\begin{array}{l}\text { Skor } \\
\text { Jumlah }\end{array}$ & $\begin{array}{c}\text { Nilai } \\
\text { Rata-rata }\end{array}$ & Kategor \\
\hline 1. & $\begin{array}{l}\text { Persepsi Masyarakat Terhadap } \\
\text { Kelas Menari }\end{array}$ & 309 & 3,15 & Baik \\
\hline 2. & $\begin{array}{l}\text { Persepsi Masyarakat Terhadap } \\
\text { Kursus Massage }\end{array}$ & 307 & 3,13 & Baik \\
\hline 3. & $\begin{array}{l}\text { Persepsi Masyarakat Terhadap } \\
\text { Cooking Class }\end{array}$ & 290 & 2,95 & Baik \\
\hline 4. & $\begin{array}{l}\text { Persepsi Masyarakat Terhadap } \\
\text { Perpustakaan Desa }\end{array}$ & 288 & 2,93 & Baik \\
\hline 5. & $\begin{array}{l}\text { Persepsi Masyarakat Terhadap } \\
\text { Kons ervasi Air }\end{array}$ & 276 & 2,81 & Baik \\
\hline 6. & $\begin{array}{l}\text { Persepsi Masyarakat Terhadap } \\
\text { Pembagian Bibit Kopi }\end{array}$ & 307 & 3,13 & Baik \\
\hline 7. & $\begin{array}{l}\text { Persepsi Masyarakat Terhadap } \\
\text { Natural and Conseravtion } \\
\text { Activity }\end{array}$ & 290 & 2,95 & Baik \\
\hline & Total & \multirow{2}{*}{\multicolumn{2}{|c|}{$\begin{array}{c}2067 \\
3\end{array}$}} & Baik \\
\hline & Rata-Rata & & & \\
\hline
\end{tabular}

Sumber: Diolah dari data penelitian, 2018

Berdasarkan data pada Tabel 15 persepsi masyarakat terhadap CSR pada Puri Lumbung Cottages telah memberikan dampak baik atau positif terhadap kehidupan sosial ekonomi masyarakat di Desa Munduk. Secara keseluruhan dampak CSR memberikan dampak baik terhadap kehidupan sosial ekonomi masyarakat. Hal tersebut dapat dilihat dari persepsi masyarakat di atas, dari 
keseluruhan indikator tersebut mayoritas masyarakat menyatakan baik dan beberapa indikator masyarakat menyatakan tidak baik.

\section{KESIMPULAN}

CSR memiliki peran yang penting karena mempengaruhi semua aspek operasi perusahaan. Artinya, semakin konsumen ingin membeli produk dari perusahaan yang mereka percaya maka pemasok semakin berminat untuk membentuk kemitraan bisnis dengan perusahaan-perusahaan mereka, karyawan ingin bekerja untuk perusahaan, dana investasi yang besar ingin mendukung perusahaan-perusahaan yang mereka anggap bertanggung jaw ab secara sosial, dan organisasi nirlaba dan LSM ingin bekerja sama dengan perusahaan untuk mencari solusi praktis untuk tujuan bersama. Kepuasan yang dirasakan masing-masing stakeholders memungkinkan perusahaan untuk memaksimalkan komitmen mereka untuk pemiliknya (pemegang saham utama) yang mendapat manfaat paling besar ketika semua kebutuhan kelompok-kelompok ini terpenuhi. Beberapa alasan mengapa CSR perlu dilaksanakan:

1. Merupakan hal etis yang dilakukan

2. Meningkatkan citra perusahaan

3. Hal ini diperlukan dalam rangka untuk menghindari peraturan yang berlebihan

4. Jenis kegiatan dari tanggung jaw ab sosial dapat juga menguntungkan

5. Lingkungan sosial yang lebih baik akan bermanfaat bagi perusahaan

6. Dapat menarik minat para investor

7. Dapat meningkatkan motivasi karyawan

8. Dapat membantu untuk memperbaiki masalah sosial yang disebabkan oleh bisnis.

Implementasi CSR yang dilakukan oleh Puri Lumbung Cottages yaitu: bentuk implementasi people yakni kelas menari oleh Puri Lumbung Cottages, kursus massage, cooking class, dan perpustakaan baca, bentuk implementasi planet yaitu sebagai pemasok air, pembagian bibit kopi, natural and activity dan bentuk implementasi profit yaitu kepemilikan lokal, partisipasi, akuntabilitas dan pelatihan.

Persepsi masyarakat terhadap implementasi CSR kelas menari yaitu 19 responden memberikan tanggapan sangat baik dan 4 orang responden memberikan tanggapan tidak baik. Persepsi masyarakat terhadap kursus massage sebanyak 18 responden memberikan tanggapan sangat baik. Sedangkan 5 orang responden memberikan tanggapan tidak baik. Persepi masyarakat terhadap implementasi perpustakaan baca yaitu sebanyak 18 responden memberikan tanggapan sangat baik dan 24 orang responden memberikan tanggapan tidak baik, dikarenakan minat membaca anak - anak di Desa Munduk sangat kurang. Terdapat 5 responden memberikan tanggapan sangat baik terhadap implementasi CSR konservasi air, sedangkan 23 orang responden memberikan tanggapan tidak baik. Persepsi masyarakat terhadap implementasi CSR pembagian bibit kopi terdapat 18 responden memberikan tanggapan sangat baik dan 5 orang responden memberikan tanggapan tidak baik.Terdapat 21 responden memberikan tanggapan sangat baik dalam implementasi CSR natural and activity, sedangkan 25 orang responden memberikan tanggapan tidak baik, dikarenakan belum pernah ikut dalam pelatihan.

\section{Ucapan terima kasih}

Saya mengucapkan terima kasih kepada Dekan Fakultas Pariw is ata Universitas Udayana yang telah memberikan dukungan sehingga kegiatan Laporan Akhir ini bisa berjalan. Terima kasih juga kami sampaikan kepada Ketua Program Studi Diploma IV Pariwisata Fakultas Pariwisata atas fasilitas dan dukungan moral yang telah diberikan. Terima kasih juga saya sampaikan kepada kedua pembimbing saya yang telah membimbing dan mengarahkan penulis dalam menyelesaikan jurnal.

Terima kasih juga kepada owner, general manager dan staff Puri Lumbung Cottages yang telah meluangkan waktunya untuk memberikan informasi dan masukan serta data yang diperlukan dalam penelitian ini, serta semua pihak yang tidak dapat kami sebutkan satu persatu yang telah banyak membantu hingga terselesaikannya penelitian ini. 


\section{DAFTAR PUSTAKA}

Dantes, Nyoman.2012.Metode Penelitian, Yogyakarta : CV. Andi Offset

Heryani, Titin dan Zunaidah. 2013. Analisis Pengaruh Penerapan Corporate Social Responsibility (Diversity \& Employee Support) Terhadap Kinerja Karyawan (Studi Kasus PT. Batu Rona Adimulya). Jurnal Manajemen Dan Bisnis Sriwijaya Vol.2 Juni 2013.

Kharisma Putra, Dewa Gede. 2016. "Implementasi Corporate Social Responsibility Hotel The Lovina Bali Di Desa Kalibukbuk Kecamatan Buleleng Kabupaten Buleleng Bali”. Sebuah Skripsi Fakultas Pariw isata Universitas Udayana, Bali.

Mardikanto, Totok. 2014. Corporate Social Responsibility (Tanggung Jawab Sosial Korporasi). Bandung : Alpabeta

Nugroho Wicaksono, Agung Prasetyo. 2017. Corporate Social Responsibility Disclousure Dan Earning Response Coefficient. AKUNTABEL Vol. 14 No. 22017

Prayogo, Dody. 2013. Measuring Corporate Social Responsibility for local communities in Mining, Oil and Gas Industries, The Case of Indonesia dalam http://iiste.org/journals/index.php/JEDS/article/download/4097/4125 (Diakses pada tanggal 03 Mei 2018)

Rai Utama, I Gusti Bagus. 2016. Metodelogi Penelitian Pariwisata dan Hospitalitas (Dilengkapi Studi Kasus Penelitian). Denpasar : Pustaka Larasan

Seravina, Marisa. Pengaruh Penerapan Corporate Social Responsibility Terhadap Nasabah Tabungan Britama dalam https://philpapers.org Diakses pada tanggal 28 Agustus 2018)

Sugiarto, Endar. 1998. Operasional Kantor Depan Hotel (Hotel Front Office Operationals), Jakarta : PT Gramedia Pustaka Utama

Sugiyono. 2014. Metode Penelitian Kuantitatif Kualitatif dan R\&D. Bandung : Alpabeta

Vegaw ati, Silvania Mira. Dkk. 2015. Pengaruh Program Corporate Social Responsibility (Csr) Terhadap Citra Perusahaan. Jurnal Administrasi Bisnis (JAB) Vol. 20 No. 1 Maret 2015.

Wardiyanta. 2006. Metodelogi Penelitian Pariwisata, Yogyakarta : CV Andi Offset

Wiyasha, IBM. 2010. Akuntansi Perhotelan. Yogyakarta : Andi

Yunita, Anggraeni. 2013. Biaya Sosial Sebagai Bagian Corporate Social Responsibility Dalam Sudut Pandang Akuntansi dalam journal.feb.unmul.ac.id (Diakses pada tanggal 28 Agustus 2018) 